\title{
Critical Habitat and the Conservation Ecology of the Freshwater Parasitic Lamprey, Lampetra macrostoma
}

\author{
R. J. BEAMISH ${ }^{1}$ and J. WADE ${ }^{2}$ \\ ${ }^{1}$ Fisheries and Oceans Canada, Pacific Biological Station, 3190 Hammond Bay Road, Nanaimo, British Columbia V9T 6N7 \\ Canada; e-mail: Richard.Beamish@pac.dfo-mpo.gc.ca \\ ${ }^{2}$ Fundy Aqua Services, 1619 Venlaw Road, Nanaimo, British Columbia V9S 1J3 Canada; email: joy2004wade@yahoo.ca
}

Beamish, R. J., and J. Wade. 2008. Critical habitat and the conservation ecology of the freshwater parasitic lamprey, Lampetra macrostoma. Canadian Field-Naturalist 122(4): 327-337.

Lampetra macrostoma, the Cowichan Lamprey, is a freshwater parasitic lamprey that probably evolved from L. tridentata within the last 10000 years. It is unique to the Cowichan Lake watershed on Vancouver Island, British Columbia, Canada. Larval rearing in Mesachie and Cowichan lakes occurs in shallow, silt-covered gravel areas at the mouths of rivers and streams flowing into the lakes. Spawning occurs over a protracted period from early May until about late July. Shallow areas with small gravel along the shore of the lakes, near the mouths of rivers are essential for successful spawning. Adults prey on a variety of salmonid species within the lake. There has been considerable development around Mesachie Lake and reported increased fishing pressure on prey in Mesachie and Cowichan lakes. It is not known if the size of the population of L. macrostoma has changed since an initial study in the early 1980 s, but a study in 2008 captured very few spawning lamprey in Mesachie Lake, possibly indicating that the population is declining.

Key Words: Cowichan Lamprey, Lampetra macrostoma, critical habitat, conservation, Mesachie Lake, Cowichan watershed, British Columbia.

The lamprey Lampetra macrostoma was first described in 1982 (Beamish 1982) as a freshwater parasitic derivative of Lampetra tridentata. It differs from $L$. tridentata because of the size of its oral disc, which in immature L. macrostoma ranges from 8.8 to $11.4 \%$ of the total length (TL) compared to 4.6 to $9.1 \%$ TL for L. tridentata (Beamish 1982). L. macrostoma is also distinguished from $L$. tridentata by a longer prebranchial length, a larger eye, weakly pigmented velar tentacles and an ability to remain and feed in fresh water prior to spawning (Beamish 1982). Youson et al. (1988) showed that there are differences in the pancreatic tissue distribution that would further support the separation of L. macrostoma and L. tridentata. Beamish (1982) held recently metamorphosed $L$. macrostoma and L. tridentata in fresh water beginning in October. By the end of November, $50 \%$ of L. tridentata had died and the remaining L. tridentata animals had died by March of the following year. All of the L. macrostoma survived.

Lampetra macrostoma spawn later in the year and at a smaller size (Beamish 1982) than most L. tridentata. Beamish and Neville (1992) showed that spawning success of lamprey declined when the length differences between male and female spawning lamprey differed by more than $20 \%$. At size differences greater than approximately $25 \%$, spawning was not successful. Thus it is unlikely that L. macrostoma could interbreed with larger, anadromous $L$. tridentata. It is likely that homogamy [the need for spawning male and female lampreys to be of equal size (Hardisty and Potter (1971a)] is the mechanism that contributed to the isolation of L. macrostoma from L. tridentata. Addi- tionally, different spawning times and locations could contribute to the speciation.

Recently, McPhail (2007) reported that the taxonomic status of L. macrostoma was unclear. McPhail and Lindsey (1970) considered that a species designation was appropriate if the fish in the population were morphologically distinguishable and not successfully interbreeding with closely related species. L. macrostoma and $L$. tridentata are morphologically distinguishable. It has not been determined if L tridentata are present in Mesachie and Cowichan lakes but they are in the Cowichan watershed. However, if the two species do or did occur sympatrically, it is unlikely that they are capable of interbreeding because of the smaller size and late spawning time of $L$. macrostoma compared to L. tridentata (Beamish and Neville 1992). It is also relevant that the morphological differences between $L$. macrostoma and L. tridentata are consistent with differences used to separate other species of lampreys. Lampetra ayresii, for example, was originally distinguished as a species from L. fluviatilis because of a larger eye, a longer prebranchial and a shorter branchial region (Vladykov and Follett 1958). L. richardsoni was mainly distinguished from L. planeri by a longer branchial region (Vladykov and Follett 1965). The differences that separate L. macrostoma and L. tridentata are also consistent with the differences that separate the derivatives of $L$. tridentata (Table 1 ). Thus, the designation of $L$. macrostoma as a distinct species is important as it is clearly distinguishable from $L$. tridentata and needs to be managed separately.

It is probable that the differences between $L$. macrostoma and L. tridentata developed in the last 10000 
TABLE 1. Characters that distinguish derivatives of Lampetra tridentata.

\begin{tabular}{lll}
\hline \hline Species & Distinguishing characters & Reference \\
\hline L. similis & Larger disc & Vladykov and Kott 1979 \\
& Smaller eye & \\
\hline L. macrostoma & Fewer velar tentacles & Beamish 1982 \\
& Larger disc & \\
& Longer pre branchial length & \\
& Larger eye & Bond and Kan 1973 \\
& In freshwater & Lorion et al. 2000 \\
\hline L. minima & Small size & \\
& Remains in freshwater & \\
& Fewer velar tentacles & \\
& Large eye & Hubbs and Potter 1971 \\
& Longer pre branchial length & Vladykov and Kott 1976b \\
& Non parasitic & Vladykov and Kott 1976a \\
L. lethophaga & Fewer velar tentacles & \\
L. folletti & Non parasitic & \\
& Fewer velar tentacles & \\
\hline L. hubbsi & Nonge disc & Vladykov and Kott 1976b \\
& Reduced dentition & Vladykov and Kott 1984 \\
\hline \hline
\end{tabular}

years after the last glaciation of the area and after the drainage of Cowichan Lake changed (Beamish 1982). There are other examples of recent and rapid speciation among lamprey. The nonparasitic species, L. planeri, for example was considered by Hubbs and Potter (1971) to have separated from L. fluviatilis within the past 10000 years. The mechanisms that result in rapid speciation within lampreys are not known, but are believed to be a factor in the success of lampreys over the past millions of years (Beamish 1985). L. macrostoma and its ecosystem provide an excellent opportunity to study the processes that form species of lamprey and species in general. Thus, although it may be worrisome to understand how L. macrostoma diverged from L. tridentata, we consider that there is not only ample precedent to maintain the designation of L. macrostoma as a distinct species but there is also an obligation to protect the species.*

In this report we present information about the critical habitat of L. macrostoma collected at the time the species was first described, but not previously published. We use this information and the results of a recent study in Mesachie Lake to comment on the im- portance of ensuring that L. macrostoma and its ecology are protected. We also identify areas of research that will help understand how L. macrostoma evolved and suggest how lampreys in general adapt to changing ecosystems by changing their life history.

\section{Study Area}

Mesachie Lake (Figure 1) is located in south central Vancouver Island, Canada (48 $\left.48^{\prime} 50^{\prime \prime} \mathrm{N}, 124^{\circ} 06^{\prime} 54^{\prime \prime} \mathrm{W}\right)$. It is a small lake with an elevation of $168 \mathrm{~m}$, a total surface area of $59.3 \mathrm{ha}$, a maximum depth of $32 \mathrm{~m}$ and a mean depth of $19.3 \mathrm{~m}$ (Province of British Columbia, GeoBC ${ }^{*}$ ). Two streams flow into Mesachie Lake. Halfway Creek flows into the east end of Mesachie Lake. Mill Creek is a small intermittent stream flowing into the southwest corner of the lake in the winter that is virtually dry in the summer. Mesachie Creek connects Mesachie Lake to Bear Lake, which then flows into McKenzie Bay in Cowichan Lake (Figure 1). Mesachie Creek has intermittent flows and can be completely dry in areas in the summer. In some years the creek was dry in areas by early May. Cowichan Lake connects to the Strait of Georgia through the Cowichan

\footnotetext{
* Lampetra macrostoma was given the common name, Lake Lamprey (Beamish 1982) because the species spawned and spent its larval and adult life in a lake. The anadromous parasitic lamprey L. ayresii that spawns and rears as an ammocoete in large rivers (Beamish 1980) has the common name, River Lamprey and it seemed fitting that L. macrostoma could be identified as the Lake Lamprey. However, Nelson et al. (2004) changed the name to the Vancouver Lamprey. The common name Vancouver Lamprey has little meaning as it implies that the species is associated with the city of Vancouver. The name Cowichan Lake Lamprey or Mesachie Lake Lamprey does make sense as the species occurs in both these lakes (Figure 1). However, if the common name must change, we prefer the name Cowichan Lamprey in reference to its occurrence in the Cowichan Lake drainage.
} 


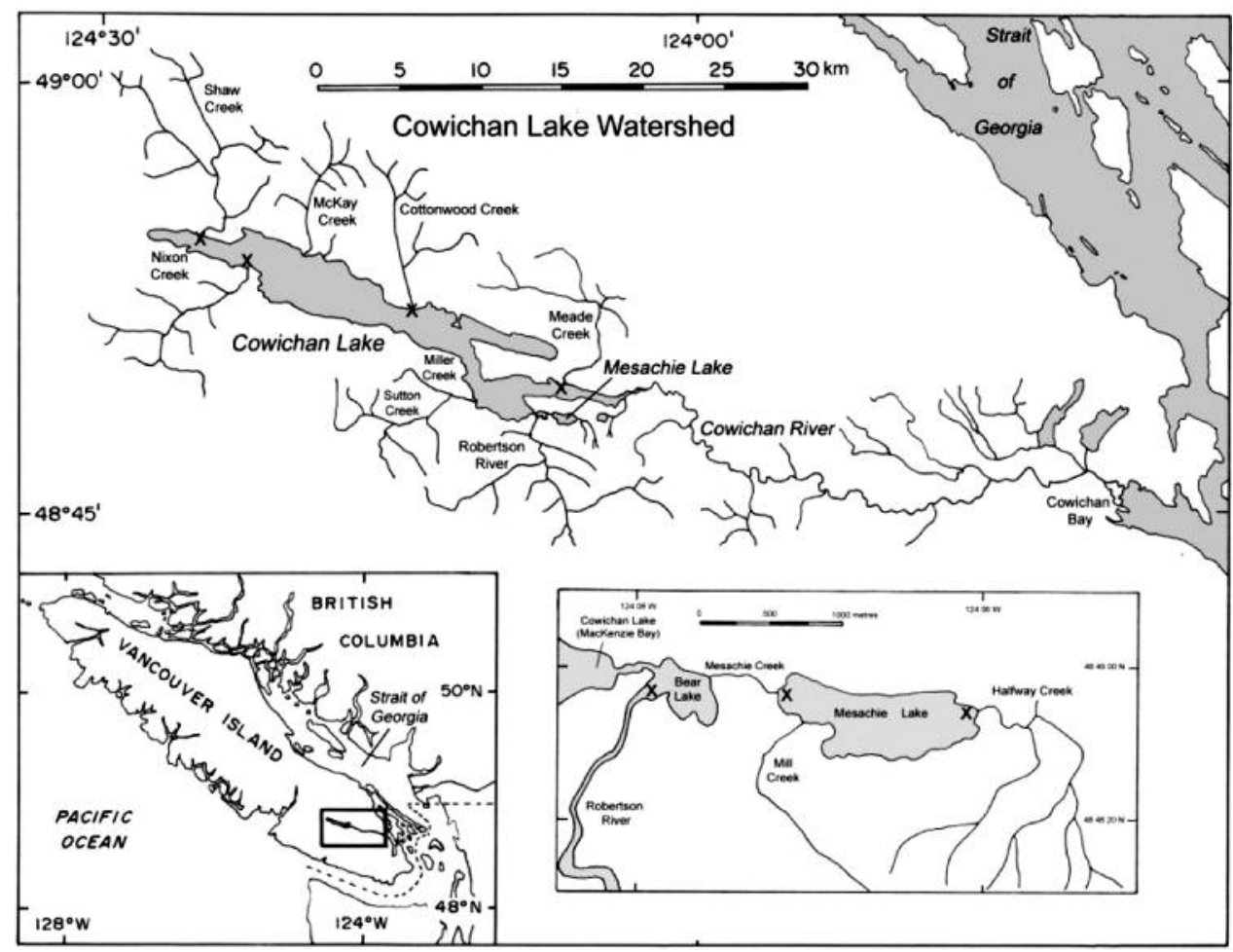

FIGURE 1. Map of Cowichan Lake watershed including a detailed inset map of Mesachie Lake and location of electroshocking sites where ammocoetes were present $(\mathrm{X})$.

River. Cowichan Lake and Mesachie Lake have a similar elevation $(164 \mathrm{~m})$, but Cowichan Lake is much larger with a surface area of 6204.3 ha and a maximum depth of $152 \mathrm{~m}$. The Cowichan River flows out of the southeast end of Cowichan Lake (Figure 1) and into the Strait of Georgia, a linear distance of 35 $\mathrm{km}$ from the lake outlet to the river mouth.

\section{Methods}

\section{Initial Study}

The first studies of $L$. macrostoma occurred from 1979 to 1985 . Initially, it was not known that it was a distinct species and the studies identified the rearing areas of ammocoetes and the adult spawning areas of what was believed to be a nonanadromous form of $L$. tridentata. The habitat used by ammocoetes was determined in Mesachie Lake and Cowichan Lake using electroshockers. Virtually all of the shallow shoreline around Mesachie Lake was surveyed. Selected areas in Cowichan Lake were surveyed and only the sites that contained ammocoetes were identified. In May 1982, bottom depths greater than $2 \mathrm{~m}$ were electroshocked from a boat. Spawning lampreys in Mesachie Lake were collected using traps (Figure 2a). Traps were set from the late spring to early summer on the gravel bar at the junction of Halfway Creek and Mesachie
Lake (Figure 1). In 1980 and 1981, unbaited wire minnow traps were placed along a mesh barrier. A trap net was positioned at the deep end of the barrier (Figure $2 \mathrm{~b}$ ). A barrier and a similar trapping arrangement were placed near the mouth of the Robertson River in 1981. The Robertson River flows into Bear Lake which is downstream from Mesachie Lake and drains into Cowichan Lake (Figure 1). In the summer and fall there may be no surface flow from the river into Bear Lake. Surveys of ammocoetes and metamorphosing juvenile lamprey were carried out in the Cowichan River between 1985 and 1988, after the lamprey in Mesachie and Cowichan lakes were recognized as a distinct species. All ammocoetes were identified using the criteria in Richards et al. (1982). It is important to note that ammocoetes of $L$. macrostoma could not be distinguished from ammocoetes of $L$. tridentata using the approach in Richards et al. (1982). Metamorphosed and adult lamprey were readily identified using disc and eye size.

\section{Coho Salmon Study}

A separate study of Coho Salmon (Oncorhynchus kisutch) movement in and out of Mesachie Lake occurred from 1988 to 1996. This area was chosen because the Cowichan Lake drainage area traditionally was a major spawning area for Coho Salmon. Ana- 
dromous Coho Salmon spawn in Halfway Creek. A fence was installed $365 \mathrm{~m}$ downstream of the junction of Mesachie Creek and Mesachie Lake. Traps were installed at the fence that captured all downstream and upstream migrating fish. As a part of this seasonal monitoring program, which took place mainly between October and January, lamprey ammocoetes and metamorphosed lampreys that were found in the traps were also enumerated.

Metamorphosed lampreys were not identified using morphometric measurements, and no specimens were saved. In many cases, there were no written reports separating ammocoetes from metamorphosed individuals or separating mature adults from recently metamorphosed individuals. Counts and date of capture of lampreys, however, were recorded. It is probable that the ammocoetes were all L. macrostoma but it is not possible to distinguish them from L. tridentata, except that spawning L. tridentata have not been reported in the same areas. When Coho Salmon smolts were caught it was noted whether or not they had lamprey scars and fresh wounds. A series of reports by Aquatic Resources Ltd. (available from the library at the Pacific Biological Station, Nanaimo, British Columbia) summarized the annual observations of this study. Our summary is based on the original field records which were given to us, and the reports by Aquatic Resources Ltd.

\section{Recent Study}

In May and June of 2008, trapping experiments were repeated in Mesachie Lake as they had been conducted in 1980 and 1981 but without the trapnet at the deep end of the barrier fence and at both the inlet and outlet streams to Mesachie Lake. Trap lines were set up with unbaited minnow traps along a black Vexar fence held in place with rebar, at the junctions. Initially, traps were checked every day. After the first two weeks, traps were checked every second day. The contents of individual traps were identified and animals released.

\section{Results}

Ammocoetes were found in selected shallow areas along the shore of Mesachie Lake and Cowichan Lake (Figure 1). Ammocoetes were found in bottom habitat where a thin layer of silt covered firmer sediments that included fine sand and small gravel or fine woody debris. Ammocoetes were not found in shallow areas where silt was deeper than about $10 \mathrm{~cm}$. In Mesachie Lake, most ammocoetes were found along the shoreline close to the inlet stream. Some ammocoetes were of in the inlet stream within approximately $100 \mathrm{~m}$ of the lake but none were found beyond this area. Very few ammocoetes were found in the outlet stream. Small numbers $(<10)$ of ammocoetes were observed in the lake in the immediate vicinity of the outlet stream, but the catches were substantially smaller than around the mouth of the inlet stream.

It was difficult to determine if ammocoetes occurred in deeper areas. However, on 7 May, 1982, six ammocoetes (120.0-150.0 mm) and one mature adult were captured after $3 \frac{1}{2} \mathrm{hr}$ of electroshocking from a boat in areas approximately $2 \mathrm{~m}$ deep immediately in front of the main inlet stream.

A shallow, silt covered, small gravel bar along the east shore of Bear Lake at the junction of the Robertson River contained ammocoete densities in 1979 and 1980 that were estimated to be about one third of the density in the gravel areas around the mouth of the inlet creek in Mesachie Lake. On 20 September, 1985 a sample of five recently metamorphosed L. macrostoma ranged from $108 \mathrm{~mm}$ to $127 \mathrm{~mm}$ and averaged $115 \mathrm{~mm}$. A sample of 64 ammocoetes ranged from $68 \mathrm{~mm}$ to $138 \mathrm{~mm}$ and averaged $102 \mathrm{~mm}$.

Ammocoetes were collected in the shallow silt covered, small gravel areas of Cowichan Lake from 1980 to 1982, near the mouths of Nixon Creek, Shaw Creek, Cottonwood Creek and near the outlet of Meade Creek (Figure 1). Ammocoetes were not found in any of the rivers flowing into the lake beyond about $100 \mathrm{~m}$ from the mouth of the river. In May 1980, a sample of 227 ammocoetes ranging in length from about 100 to $170 \mathrm{~mm}$ was collected from the shallow gravel and fine sediment area adjacent to Shaw Creek. They were transported to the laboratory at the Pacific Biological Station, Nanaimo, British Columbia where they were fed brewer's yeast until October 1981 when 59 had completed metamorphosis. All 59 were determined to be L. macrostoma (Beamish 1982). Thus, it was confirmed that ammocoetes of L. macrostoma were in the shallow gravel areas near the mouth of Shaw Creek in particular and probably in similar areas near rivers that flow into Cowichan Lake.

\section{Other Species of Ammocoetes}

No L. richardsoni ammocoetes were found in any of the collections from the lakes or rivers flowing into Cowichan Lake or in Mesachie Lake. However, the surveys of rivers flowing into Mesachie Lake and Cowichan Lake were restricted to distances less than about $100 \mathrm{~m}$ from the river mouth. Ammocoetes of $L$. ayresii are readily identified (Richards et al. 1982) and none were found.

\section{Spawning Habitat and Spawning Times}

Lampetra macrostoma in spawning condition were captured in the gravel areas adjacent to the mouths of the inlet creek in Mesachie Lake and the Robertson River from mid-May until late August (Figure 1). On 2 May 1982, one mature L. macrostoma was captured in Halfway Creek, a short distance from the lake. This was the only adult L. macrostoma captured in any of the river and creek electroshocking studies. No lampreys were observed spawning or guarding nests despite frequent visits by people attending the traps.

In 1980, 124 mature and maturing L. macrostoma were captured in the traps at the barrier fence in Mesachie Lake between 3 May and 18 August (Figure 3). Traps were set between 3 May and 18 September. 


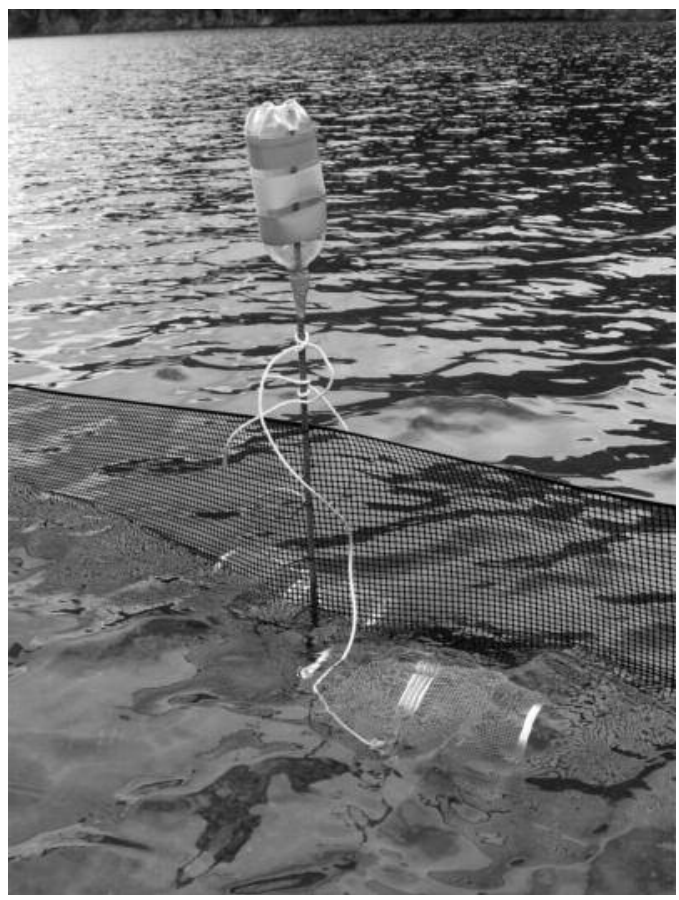

FIGURE 2a. Photograph of unbaited minnow traps along a mesh barrier to form a trap line in Mesachie Lake.

Catches were evenly spread out in May and June, with slightly smaller catches in July and up to mid-August. Male lampreys $(n=83)$ averaged $211 \mathrm{~mm}$ (range from $179 \mathrm{~mm}$ to $272 \mathrm{~mm}$ ) and 41 female lampreys averaged $204 \mathrm{~mm}$ (range from $182 \mathrm{~mm}$ to $256 \mathrm{~mm}$ ) (Figure 4). In 1981, the trap net at the offshore end of the barrier fence was not used and minnow traps were in place from 18 April to 25 July. Catches of $L$. macrostoma from 16 May to 23 July totalled 21 mature lampreys (Figure 5). The traps were in place at the mouth of the Roberston River in 1981 from 9 June to 29 July. A total of 26 mature L. macrostoma were captured from 15 June to 21 July (Figure 5). Most lampreys were captured in mid-June (Figure 5). Lamprey spawning nests were distinguishable in the gravel area by circular areas of "cleaned" gravel about 6-12 cm in diameter. New spawning nests were commonly observed in June in both trapping areas.

\section{Surveys of Lampreys in the Cowichan River}

Ammocoetes of L. richardsoni and L. tridentata were common in the Cowichan River. In October 1988, recently metamorphosed $L$. tridentata and $L$. richardsoni were also captured. Ammocoetes of $L$. tridentata and L. richardsoni averaged $88 \mathrm{~mm}$ (43 $\mathrm{mm}$ to $125 \mathrm{~mm}$ ) and $126 \mathrm{~mm}$ (46 $\mathrm{mm}$ to $187 \mathrm{~mm}$ ), respectively (Figure 6). Recently metamorphosed $L$. tridentata averaged $110 \mathrm{~mm}(93 \mathrm{~mm}$ to $145 \mathrm{~mm})$ and L. richardsoni

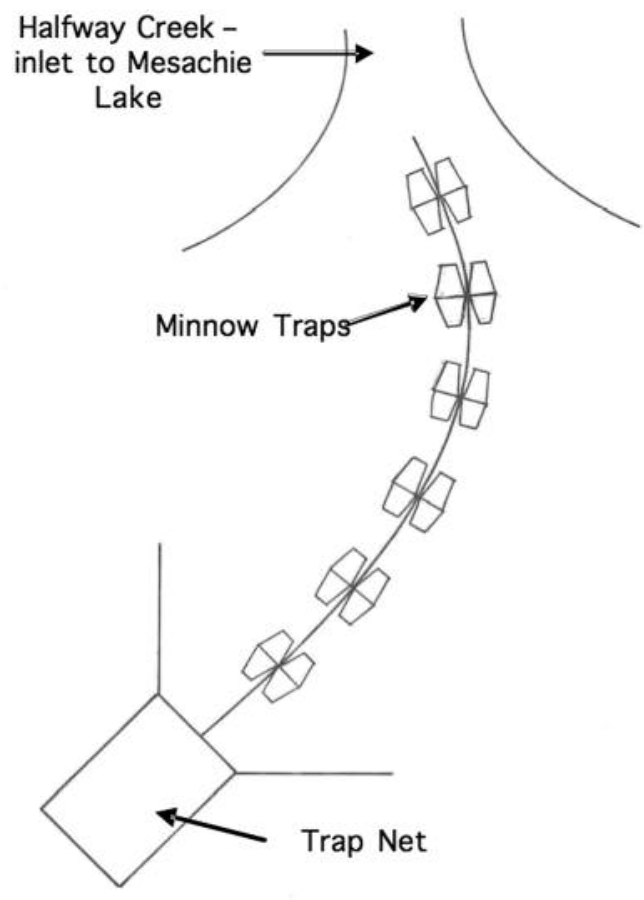

FIgURE 2b. Diagram of trap set-up at inlet of Halfway Creek to Mesachie Lake used in the 1980s. The set-up was similar in 2008 except a trap net was not used.

$167 \mathrm{~mm}(163 \mathrm{~mm}$ to $171 \mathrm{~mm}$ ) (Figure 6). The ammocoetes we identified as $L$. tridentata could not be distinguished from L. macrostoma ammocoetes, but none of the recently metamorphosed lamprey were $L$. macrostoma.

\section{Coho Salmon Study}

From 1988 until 1996, 342 lampreys were recorded in the downstream and upstream traps. All but six were recorded in the downstream traps. There were 59 lampreys identified as metamorphosed and 29 as ammocoetes. However, it is possible that more were metamorphosed, as many observations were labelled only as "lamprey". Most of the metamorphosed lampreys were identified as L. macrostoma and a few were identified as $L$. tridentata. There were six lampreys recorded in the upstream end trap. All were metamorphosed. Two were labelled as L. tridentata. Thus, 253 lampreys were recorded only as "lamprey". Coho Salmon smolts frequently had lamprey wounds and scars. For example, from 6 April to 30 June 1987, 1850 Coho Salmon smolts were examined in the downstream traps and 629 Coho Salmon smolts (34\%) had at least one lamprey scar.

\section{Recent Study and Report of Shoreline Development}

No lampreys were caught in the traps at the junction of the outlet (Mesachie Creek and Mesachie Lake) 


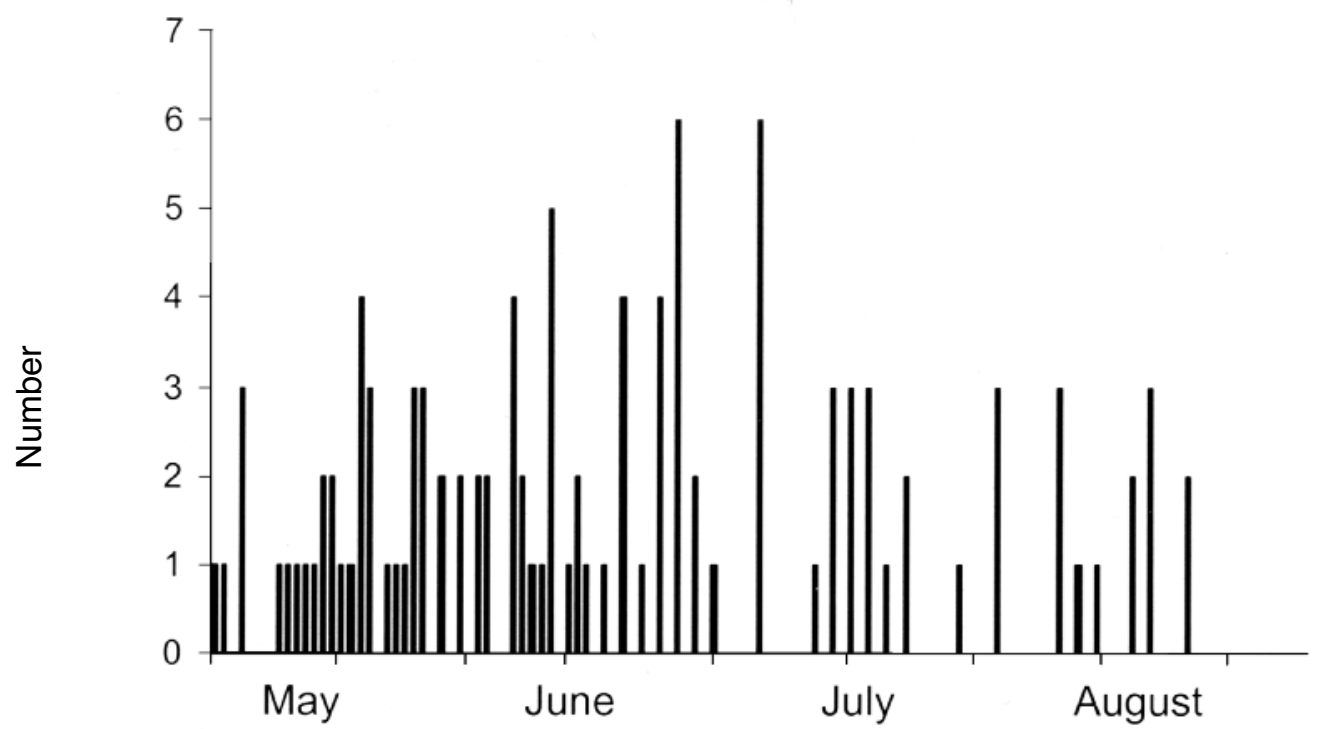

FIGURE 3. Number of mature and maturing L. macrostoma caught in traps in Mesachie Lake in 1980. Vertical lines indicate the number of lamprey caught in each day.

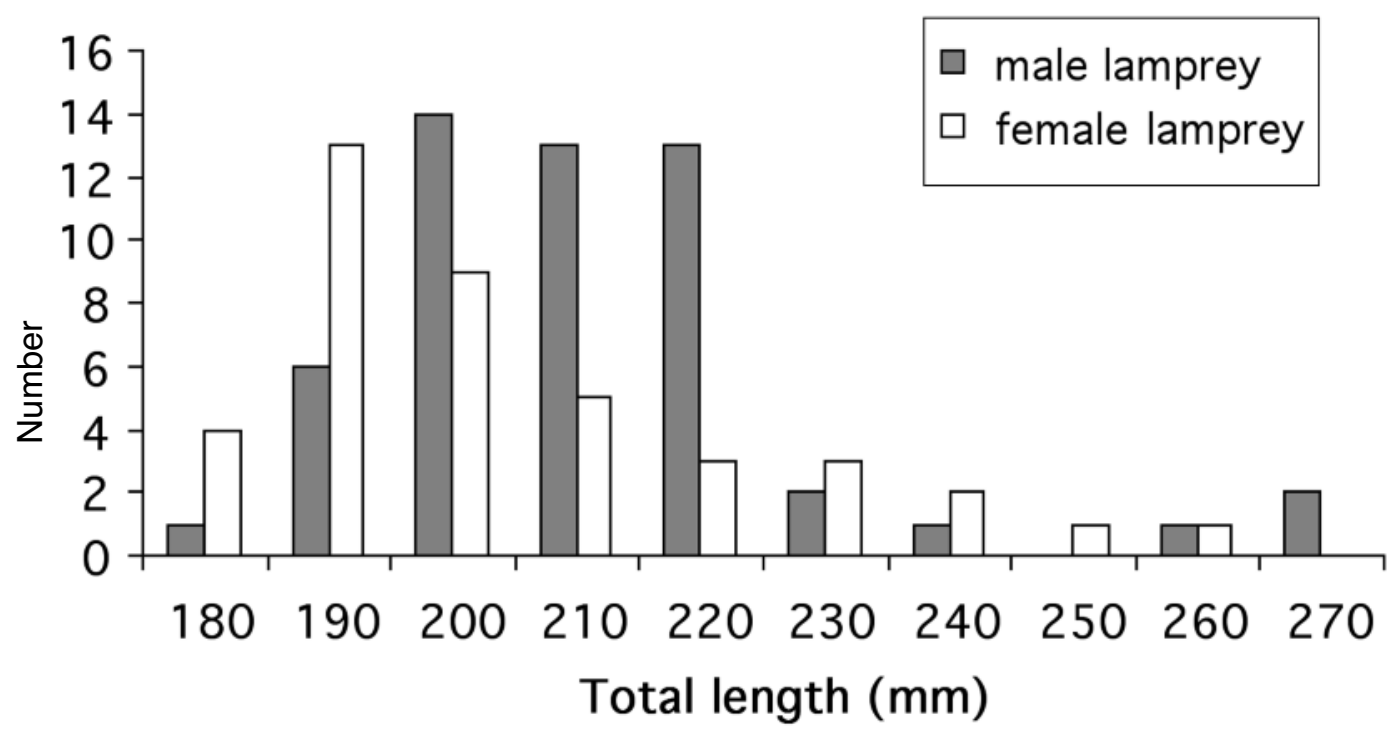

FIGURE 4. Length frequency of male and female L. macrostoma caught in 1980 in Mesachie Lake.

during the spring/summer of 2008. Four L. macrostoma were caught in the traps at the gravel area adjacent to the inlet of Halfway Creek. Other species in the traps included: Cutthroat Trout (Oncorhynchus clarki), stickleback (unidentified), sculpin (unidentified) and crayfish (unidentified) (Table 2).
The substrate in the area of Mesachie Creek is mostly mud and therefore not ideal for lamprey spawning which may be the reason we did not catch any lampreys in this area in our recent study or in the previous study. The substrate at the junction of the inlet stream, Halfway Creek and Mesachie Lake in 2008 was ap- 

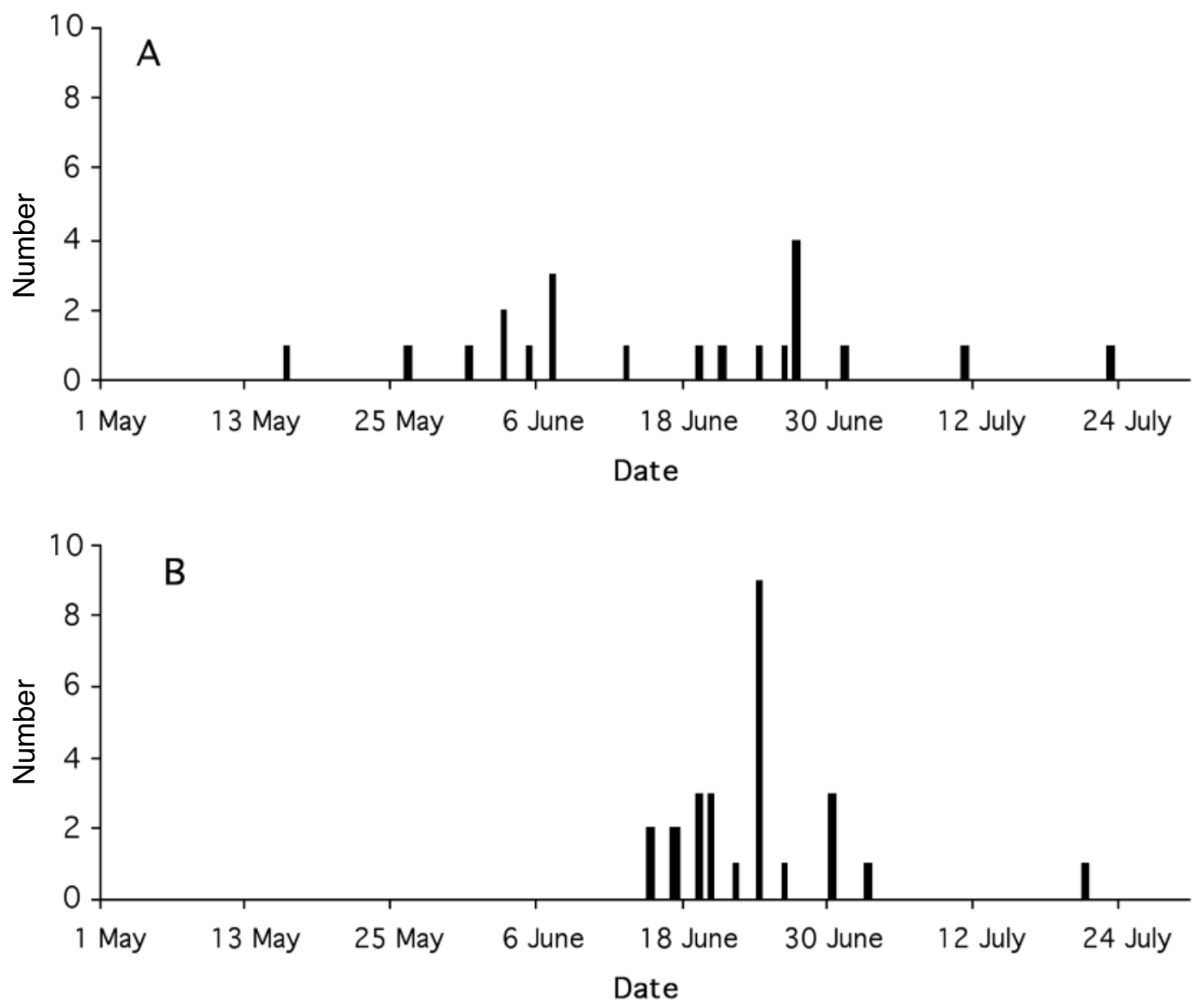

FIgURE 5. L. macrostoma catches from Mesachie Lake (A) and the mouth of Robertson River (B) in 1981.

proximately equal amounts of small gravel, fine substrate and large gravel. The critical rearing habitat is characterized by layers of fine silt and fine gravel. It does not appear that this substrate has changed since studies in the early 1980 s.

We observed that there has been significant development on Mesachie Lake in the past fifteen years. There are two new houses close to the spawning area at the inlet stream One property appears to extend up to the inlet stream itself. The other property is within $50 \mathrm{~m}$ of the spawning area. There has been no development along the main road on the south-west side of Mesachie Lake in the past fifteen years. Due to the geology of the lake there has been no development on the northeast side of the lake. This side remains as it was in the early 1980s, with a shear rock cliff that drops into the water. Because of this abrupt drop-off, there are no beaches or potential spawning grounds in this area.

The area of the lake where the outlet stream is located has undergone significant development since the 1980s. Houses and cottages have been built along with Camp Imadene. Camp Imadene is a new facility (first campers in 1992) and is located at the former site of the Hillcrest Lumber Company. Camp Imadene currently owns 55 acres around Mesachie Lake and it is believed that they own the rights to the lakebed. New residents along the lakeshore have cleaned out the riparian zone over much of this area and brought in fine gravel to create beaches. The new "beaches" created by landowners may provide potential spawning areas because of the addition of fine substrate to the foreshore; however, trapping studies were not conducted on these beaches in 2008 .

Most of the houses and the large camp have their own docks and boats and some residents live at the lake all year. Through conversations with long time residents along the lake, it is clear that there is significant activity on the lake during the summer. There are many boaters and fishermen, in particular there seems to be significant activity from the camp with numerous boats 

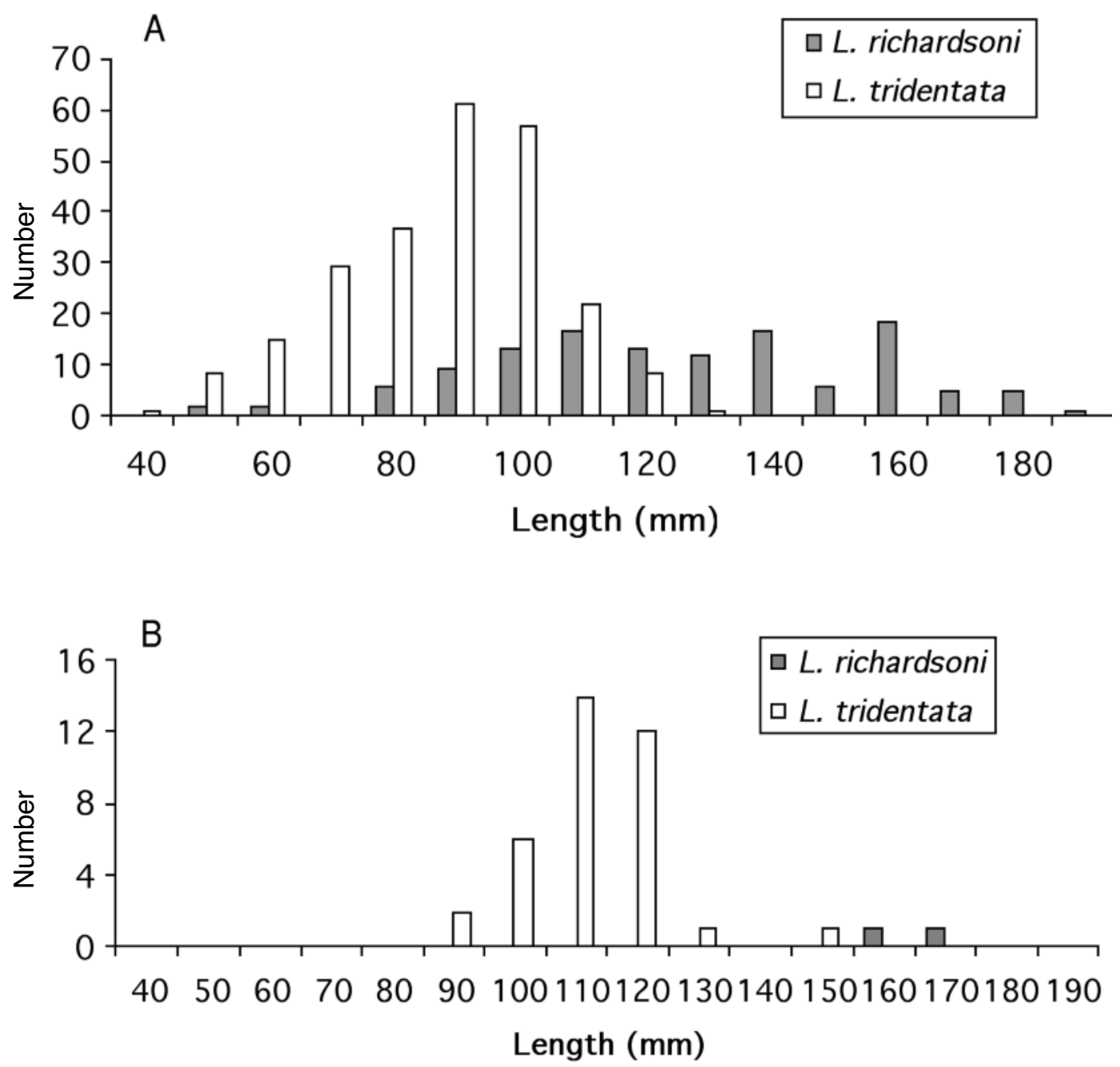

FIGURE 6. (A) Length frequency of L. richardsoni ammocoetes $(n=126)$ collected in July $1985(n=30)$, September 1985 $(n=7)$ and October $1988(n=89)$ and L. tridentata $(\mathrm{N}=239)$ ammocoetes collected in July $1985(n=24)$, September $1985(n=85)$ and October $1988(n=130)$. (B) Length frequency of recently metamorphosed L. richardsoni $(n=2)$ collected in September 1985 and L. tridentata $(n=36)$ collected in September 1985. The data are presented only to indicate that the lamprey were present.

and boating activities on the lake. It is not known what impact these new activities have had or will have on the lamprey population in Mesachie Lake or on lamprey prey.

The year of our recent study (2008) marked the $30^{\text {th }}$ anniversary of a children's fishing derby on Mesachie Lake. Accurate records have not been kept, but longtime residents Mr. and Mrs. E. Pawlik have hosted the derby each year. They observed that the catches related to effort have been decreasing dramatically in the last few years.

\section{Discussion}

\section{Critical Habitat}

The critical habitat for the conservation of L. macrostoma is the shallow covered gravel areas near the mouths of rivers and streams that flow into Mesachie and Cowichan lakes. It is possible that flows from these rivers are also important during the egg incubation stage. Substrate was approximately equal amounts of silt, small gravel, fine substrate and large gravel. Fine sediment on top of small gravel was the most common habitat, but ammocoetes were also found in areas with 
fine woody debris on top of firm sediment. In general, this was typical habitat for many species of lamprey (Hardisty and Potter 1971b). Substrate deeper than approximately $1 \mathrm{~m}$ was rarely sampled, but when sampled, few lamprey were found, probably indicating that the deeper areas are not major rearing areas for ammocoetes.

Ammocoete age is difficult to determine despite the attempts to use statoliths (Volk 1986; Beamish and Medland 1988) or lengths (Potter 1980; Beamish and Medland 1988) resulting in most authors repeating published estimates that were originally interpretations based on a length frequency analysis. If we assume ammocoete ages are similar to those reported by other authors (Potter 1980; Beamish and Medland 1988), then the ammocoetes may be about five years old or older when they metamorphose into the adult stage. This would indicate that the rearing habitat for the ammocoetes must remain in a natural state for long periods.

The areas containing larger concentrations of ammocoetes are also important spawning areas. We speculate that the flow from the inlet stream into the lake and over the spawning area is important. In years such as 1983 when there was very little water flow into Mesachie Lake the sand and gravel area is uncovered and lamprey spawning appears to be restricted. At these times the gravel bar in Mesachie Lake would be approximately $30 \mathrm{~m}$ in length and $2 \mathrm{~m}$ across at its widest point. Thus, even though the river bottom of inlet streams may not be an important rearing area, the flow from the stream may be important over the protracted spawning period. Lake level is also important as the shallow spawning areas can become restricted in size if lake levels are low from early May to the end of July. We have not observed L. macrostoma building nests, spawning or holding in the vicinity of the spawning area. Thus, we suspect that spawning may occur at night and that these lake spawning lamprey do not have a spawning behaviour like many lamprey that spawn in rivers (R. Beamish, personal observations). We have not compared the timing and duration of spawning of $L$. macrostoma with $L$. tridentata that spawn in the Cowichan River. However, biologists employed at a hatchery on the Cowichan River reported that $L$. tridentata that average about $35 \mathrm{~cm}$ in total length spawn from about mid-April to late May. If these reports are accurate, it confirms that L. macrostoma has a different spawning time, spawning size and spawning behaviour than L tridentata in the same watershed.

\section{Other Species of Lamprey}

We have not observed L. tridentata in Mesachie Lake or Cowichan Lake. We did collect L. tridentata in the Cowichan River and it is common to observe L. tridentata spawning in the Cowichan River. Adult Coho Salmon migrate into Mesachie Lake, so access to both Cowichan and Mesachie lakes to L. tridentata is possible. We interviewed local residents and no one
TABLE 2. Catches in the traps from the 2008 field sampling season.

\begin{tabular}{lcc}
\hline \hline Date & $\begin{array}{c}\text { Inlet area } \\
\text { L. macrostoma }\end{array}$ & $\begin{array}{c}\text { Outlet area } \\
\text { L. macrostoma }\end{array}$ \\
\hline 2 May & 0 & 0 \\
3 May & 0 & 0 \\
4 May & 0 & 0 \\
6 May & 0 & 0 \\
3 June & 1 & 0 \\
5 June & 1 & 0 \\
7 June & 0 & 0 \\
9 June & 1 & 0 \\
11 June & 0 & 0 \\
13 June & 0 & 0 \\
15 June & 1 & 0 \\
17 June & 0 & 0 \\
19 June & 0 & 0 \\
21 June & 0 & 0 \\
23 June & 0 & 0 \\
25 June & 0 & 0 \\
27 June & 0 & 0 \\
29 June & 0 & 0 \\
1 July & 0 & 0 \\
Total & 4 & 0 \\
\hline \hline
\end{tabular}

reported observing lampreys spawning in rivers flowing into Mesachie or Cowichan lakes. If L. tridentata were spawning in the two lakes it is probable, that over many decades, local residents would know that lamprey were spawning in the rivers. Thus, we speculate that if $L$. tridentata enter the lakes, it is uncommon. We therefore conclude that it is probable that all of the ammocoetes found along the shoreline of both lakes in our surveys were L. macrostoma.

It is important to confirm if adult $L$. tridentata move into Cowichan Lake from the Cowichan River. If it is confirmed that $L$. tridentata do not migrate into Cowichan Lake, it may appeal to the curious to determine why a species that is known to be capable of migrating approximately $500 \mathrm{~km}$ (Farlinger and Beamish 1984) does not migrate the relatively short distance into Cowichan Lake. A possible explanation may relate to the availability of spawning areas in the rivers flowing into Cowichan Lake.

Records from the Coho Salmon study list a few $L$. tridentata in the traps but no specimens were saved and all identifications were made without measurements or any recorded documentation. Thus, it is probable that all metamorphosed lampreys in the Coho Salmon study were $L$. macrostoma and not $L$. tridentata.

The Coho Salmon study did show that lampreys are moving out of Mesachie Lake. The stage of development was not recorded for many lampreys, but the size indicated that these lampreys were a mixture of ammocoetes and metamorphosed lampreys. The few lamprey in the upstream traps were all metamorphosed and could be individuals moving back into Mesachie 
Lake that were captured in the downstream trap and released on the downstream side. Alternatively, they could be migrating into the lake. However, the numbers were very small and the recorded sizes were in the range of sizes observed for L. macrostoma and not mature L. tridentata in general (Beamish 1980) or mature L. tridentata that spawn in the Cowichan River in late April and early May.

It is important to recognize that L. macrostoma is distinct from L. tridentata. L. tridentata is commonly found in many rivers and streams in British Columbia (R. Beamish unpublished survey data). Thus, there are probably hundreds of populations of L. tridentata in British Columbia. There are only a few L. tridentata populations that have been reported to feed in fresh water. One in Elsie Lake (Beamish and Northcote 1989) was shown to result from the construction of a dam that prevented the metamorphosed individuals from leaving the lake. It was reported that the metamorphosed lamprey fed only a short time and died. Adult lampreys were also prevented from entering Elsie Lake and it appears that the population was extirpated. Thus, although there was some feeding, the population was unable to reproduce. There are freshwater feeding L. tridentata in two other lakes in British Columbia (R. Beamish, personal communication). Neither of these populations are L. macrostoma. One population in Sakinaw Lake $\left(49^{\circ} 40^{\prime} \mathrm{N}, 124^{\circ} 00^{\prime} \mathrm{W}\right)$ consists of an anadromous form and a possible nonanadromous form, but neither form has been studied in detail. It is known from morphometric measurements that the freshwater parasitic form is not L. macrostoma (R. Beamish, unpublished data). The other known population is from West Lake on Nelson Island $\left(49^{\circ} 44^{\prime} \mathrm{N}\right.$, $\left.124^{\circ} 05^{\prime} \mathrm{W}\right)$. Specimens from this population are not $L$. macrostoma, although they differ slightly from $L$. tridentata. It is possible that if new species of lampreys can evolve in the past 10000 years as reported earlier, there will be some variation among existing populations of a wide ranging species such as $L$. tridentata. This variation, which we know only from two other populations, is not sufficient to ignore the differences between L. macrostoma and L. tridentata. Thus, it is important to maintain the species distinction of L. macrostoma and to recognize the importance of protecting its habitat and its ecology.

\section{Conservation Ecology}

Beamish (1982) reported that feeding adult L. macrostoma in Mesachie Lake readily attacked resident fishes. Up to $50 \%$ of potential prey species collected in the trap net in 1980 had some evidence of being attacked by lamprey. Carl (1953) reported that 8 of 10 fish examined from Cowichan Lake had been attacked by lamprey. Local residents reported that fish in general and Cutthroat Trout in particular in Cowichan and Mesachie lakes are often scarred by lamprey. Less commonly, fish are landed with lamprey still attached.
All lamprey specimens that we have examined that were attached to fish caught by anglers were L. macrostoma. The Coho Salmon study and an earlier study (Beamish 1982) showed that Coho smolts leaving Mesachie Lake were heavily scarred, indicating that juvenile Coho were an important prey of L. macrostoma. There are no estimates of the abundance of species such as Cutthroat Trout that are a common prey of L. macrostoma. It is known that wild Coho Salmon abundance in the areas around the Strait of Georgia (Figure 1) has declined dramatically (Beamish et al. 2008). Thus it is probable that juvenile Coho Salmon that rear in the lakes for one or two years are also in lower abundance in recent years. We received reports that catches of sport fish were declining and the development around Mesachie Lake indicates that fishing effort probably has increased. We are concerned that our trapping study in 2008 captured only four L. macrostoma. This is a much smaller catch than in 1981, when the trapping design at the inlet of Mesachie Lake was similar. Unfortunately, it is not possible to estimate lamprey abundance from scarring rates as it is not known if a high scarring rate is a consequence of reduced prey or increased lamprey abundance. If $L$. macrostoma are to be protected, it is necessary to determine the population size as quickly as possible. A standard mark and recapture study is needed to estimate the adult abundance. This could be accomplished using trap nets and marking the lamprey before and during the spawning period with latex injections into the dorsal fin fold. It is also important to ensure that prey species in the lake are not overfished. Until the abundance of L. macrostoma is known, it is important to restrict any lethal sampling of ammocoetes or adults of L. macrostoma. The impact of the recent shoreline development around Mesachie Lake also needs to be assessed.

\section{Acknowledgements}

The authors acknowledge the unwavering interest and enthusiasm of Mr. Ed Pawlik for our project and for L. macrostoma, Wendy Mitton and Mike Smith for their many years of support for the lamprey program and for their shocking assistance in the Mesachie and Cowichan lakes study. Thank you to Steve Baillie for the Coho Salmon study data. Thank you to Lana Fitzpatrick for her assistance in the preparation of this manuscript.

\section{Documents Cited (marked * in text)}

Province of British Columbia, GeoBC. Ministry of Environment (Government of British Columbia). Bathymetric map of Mesachie Lake. Available at http://a100.gov.bc.ca/ pub/fidq/bath_images/pdf/00186001.pdf.

\section{Literature Cited}

Beamish, F. W. H., and T. E. Medland. 1988. Age determination of lampreys. Transactions of the American Fisheries Society 117:63-71. 
Beamish, R. J. 1980. The adult biology of the river lamprey (Lampetra ayresii) and the Pacific lamprey (Lampetra tridentata) from the Pacific coast of Canada. Canadian Journal of Fisheries and Aquatic Sciences 37: 1906-1923.

Beamish, R. J. 1982. Lampetra macrostoma, a new species of freshwater parasitic lamprey from the west coast of Canada. Canadian Journal of Fisheries and Aquatic Sciences 37: 736-747.

Beamish, R. J. 1985. Freshwater parasitic lamprey on Vancouver Island and a theory of the evolution of the freshwater parasitic and nonparasitic life history types. Pages 123-140 in Evolutionary Biology of Primitive Fishes. Edited by R. E. Foreman, A. Gorbman, J.M. Dodd, and R. Olsson. Plenum Publishing Corp., New York, New York.

Beamish, R. J., and C-E. M. Neville. 1992. The importance of size as an isolating mechanism in lampreys. Copeia 1992: 191-196.

Beamish, R. J., and T. G. Northcote. 1989. Extinction of a population of anadromous parasitic lamprey, Lampetra tridentata, upstream of an impassable dam. Canadian Journal of Fisheries and Aquatic Sciences 46: 420-425.

Beamish, R. J., R. M. Sweeting, K. M. Lange, and C. M. Neville. 2008. Changes in the population ecology of hatchery and wild coho salmon in the Strait of Georgia. Transactions of the American Fisheries Society 137: 503-520.

Bond, C. E., and T. T. Kan. 1973. Lampetra (Entosphenus) minima n.sp., a dwarfed parasitic lamprey from Oregon. Copeia 1973: 568-574.

Carl, G. C. 1953. Limnobiology of Cowichan Lake, British Columbia. Journal of the Fisheries Research Board of Canada 9: 417-449.

Farlinger, S. P., and R. J. Beamish. 1984. Recent colonization of a major salmon-producing lake in British Columbia by the Pacific lamprey (Lampetra tridentata). Canadian Journal of Fisheries and Aquatic Sciences 41: 278-285.

Hardisty, M. W., and I. C. Potter. 1971a. The behaviour, ecology and growth of larval lampreys. Pages 85-126 in The biology of lampreys. Volume I. Edited by M. W. Hardisty and I. C. Potter. Academic Press, London, England.

Hardisty, M. W., and I. C. Potter. 1971b. Paired species. Pages 249-277 in The biology of lampreys. Volume I. Edited by M. W. Hardisty and I. C. Potter. Academic Press, London, England.

Hubbs, C. L., and I. C. Potter. 1971b. Distribution, phylogeny and taxonomy. Pages 1-65 in The biology of lampreys. Volume I. Edited by M. W. Hardisty and I. C. Potter. Academic Press, London, England.

Lorion, M. C., D. F. Markle, S. B. Reid, and M. F. Docker. 2000. Redescription of the presumed-extinct Miller Lake lamprey, Lampetra minima. Copeia 2000: 1019-1028.

McPhail, J. D. 2007. The freshwater fishes of British Columbia. University of Alberta Press, Edmonton. 620 pages.
McPhail, J. D., and C. C. Lindsey. 1970. Freshwater fishes of northwestern Canada and Alaska. Fisheries Research Board of Canada Bulletin 173: 381 pages.

Nelson, J. S., E. J., Crossman, H. Espinosa-Perez, L. T. Findley, C. R. Gilbert, R. N. Lea, and J. D. Williams. 2004. Common and scientific names of fishes from the United States, Canada and Mexico. American Fisheries Society, Special Publication 29. Bethesda, Maryland.

Potter, I. C. 1980. Ecology of larval and metamorphosing lampreys. Canadian Journal of Fisheries and Aquatic Sciences 37: 1641-1657.

Richards, J. E., R. J. Beamish, and F. W. H. Beamish. 1982. Descriptions and keys for ammocoetes of lampreys from British Columbia, Canada. Canadian Journal of Fisheries and Aquatic Sciences 39: 1484-1495.

Vladykov, V. D., and W. I. Follett. 1958. Redescription of Lampetra ayresii (Gunter) of western North America, a species of lamprey (Petromyzontidae) distinct from Lampetra fluviatilis (Linnaeus) of Europe. Journal of the Fisheries Research Board of Canada 15: 47-77.

Vladykov, V. D., and W. I. Follett. 1965. Lampetra richardsoni, a new nonparasitic species of lamprey (Petromyzonidae) from western North America. Journal of the Fisheries Research Board of Canada 27: 139-158.

Vladykov, V. D., and E. Kott. 1976a. A second nonparasitic species of Entosphenus Gill, 1862 (Petromyzonidae) from Klamath River system, California. Canadian Journal of Zoology 54: 974-989.

Vladykov, V. D., and E. Kott. 1976b. A new nonparasitic species of lamprey of the genus Entosphenus Gill, 1862 (Petromyzonidae) from south central California. Bulletin of the South California Academy of Science 75: 60-67.

Vladykov, V. D., and E. Kott. 1979. A new parasitic species of the holarctic lamprey genus Entosphenus Gill, 1862 (Petromyzonidae) from Klamath River, in California and Oregon. Canadian Journal of Zoology 57: 808-823.

Vladykov, V. D., and E. Kott. 1984. A second record for California and additional morphological information on Entosphenus hubbsi Vladykov and Kott, 1976 (Petromyzonidae). California Fish and Game 70: 121-127.

Volk, E. C. 1986. Use of calcareous otic elements (statoliths) to determine age of sea lamprey (Petromyzon marinus). Canadian Journal of Fisheries and Aquatic Sciences 43: 718-722.

Youson, J. H., W. M. Elliott, R. J. Beamish, and D. W. Wang. 1988. A comparison of endocrine pancreatic tissue in adults of four species of lampreys in British Columbia: A morphological and immunohistochemical study. General and Comparative Endocrinology 70: 247-261.

Received 24 September 2008

Accepted 26 August 2009 